\title{
DEVELOPMENT OF REGIONAL PRICE LEVELS IN THE CZECH REPUBLIC
}

\author{
PETR MUSIL ${ }^{\mathrm{a}, \mathrm{b}, *}, \mathrm{JANA}$ KRAMULOVÁ ${ }^{\mathrm{a}, \mathrm{c}}$ \\ petr.musil@vse.cz,jana.kramulova@vse.cz \\ a University of Economics in Prague, Faculty of Informatics and Statistics, Department of Economic Statistics, \\ W. Churchill Sq. 4, Prague, Czech Republic

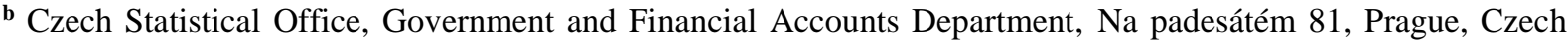 \\ Republic \\ c Czech Statistical Office, Financial Accounts Unit, Na padesátém 81, Prague, Czech Republic
}

\begin{abstract}
Regional price levels attract attention of researchers as well as of general public due to the fact that regional price differences influence the interpretation of regional indicators. The current international approach reflects just price differences among countries, and regional disparities are excluded from the calculation. Official statistics is not able to capture them mainly due to the lack of detailed regional data sources. However, in several countries including the Czech Republic, researchers estimated regional price levels using various approaches. This activity has been widely appreciated and the results have been applied in wage analyses, doctoral theses, further research, etc. The research team of the University of Economics in Prague first developed the methodology and estimated regional price levels in the Czech Republic for the year 2007. The next estimate for the year 2012 considered changes brought by the new standard of national accounts, new methods of data collection, etc. The aim of this paper is to assess the ongoing applicability of the existing methodology and estimate regional price levels for the year 2017 in Czech NUTS 3 regions. The main contribution is to answer the demand for updated estimates. Longer time series permit analyzing changes in regional price levels and in the trends of real indicators that are adjusted to price levels. The analysis also provides a useful tool for the research community for assessing the convergence of Czech regions.
\end{abstract}

\section{Key words}

regional price levels, methodological issues, Czech NUTS 3 regions, comparison, update

\section{JEL classification}

E31, R10

\section{Introduction}

Regional price levels attract attention of researchers as well as of general public due to the fact that regional price differences influence the interpretation of regional indicators. Current international approach reflects just price differences among countries and regional disparities are excluded from the calculation. Official statistics is not able to capture them mainly due to the lack of detailed regional data sources.

That is the main reason, why the field is opened to researchers all over the world. This topic is discussed in a huge number of scientific papers and the echo of regional price levels is not reducing in time. On the contrary, there are still new papers dealing with regional price levels and consequences of applying them (e.g. Rokicki and Hewings, 2019, for Poland).

In several countries including the Czech Republic researchers have estimated regional price levels using various approaches (the list of some of these approaches can be found in Janský and Kolcunová, 2017, p. 647). This activity has been widely appreciated and the results have been applied in the wage analyses, doctoral theses, further research activities etc. 
For the case of the Czech Republic see e.g. Bajgar and Janský (2015) for wage analysis in Czech NUTS 3 regions or Kocourek et al. (2016) for estimates of regional price levels in 77 Czech LAU 1 districts. Rokicki and Hewings (2016) applied regional price levels on gross domestic product (hereinafter GDP) per capita at Poland NUTS 2 level and USA state level.

This paper follows the first estimates of regional price levels in the Czech Republic for the years 2007 (Čadil et al., 2014) and 2012 (Kramulová et al., 2016). The researcher team of the University of Economics in Prague firstly developed the methodology and estimated regional price levels in the Czech Republic for the year 2007. The following estimate for the year 2012 considered changes brought by the new standard of national accounts, new methods of data collection etc. It is also necessary to point out that there is a constant demand on updated estimates.

The aim of this paper is to assess the ongoing applicability of the existing methodology and estimate regional price levels for the year 2017 in Czech NUTS 3 regions. The NUTS 3 regional level (the most detailed level of NUTS classification) contains in the Czech Republic 14 regions.

Longer time series enable to analyse changes in regional price levels and in evolution of real indicators that are adjusted to price levels. It also provides a useful tool for researcher community to analyse convergence of Czech regions (see e.g. Čadil et al., 2014).

The paper is organised as follows: Section 2 presents the actual methodology and data used for the estimates. Section 3 shows the results in the form of regional price levels for the year 2017 and also their application on wages. Section 4 brings the discussion about comparison of three estimates of regional price levels as well as application of the results on national disposable income of households in Czech regions. Section 5 is devoted to conclusion.

\section{Methodology and data}

This section will briefly introduce the data and methodology used for estimation of regional price levels. We divided the section into two, the first mentioning international comparison and the second regional comparison of economic indicators.

\subsection{International comparison of economic indicators}

Spatial comparison represents a challenging task for statisticians as price levels, consumption habits differ among countries. Comparison of indicators in various currencies may be overcome by transforming indicators to the same, usually widespread, currency such as dollar or euro. On one hand it is a very easy method that does not require additional data sources or models, on the other hand the method leads to the misleading results (European Commission and OECD, 2012). An exchange rate may express at best a relationship between price levels of negotiable products. The method has several drawbacks notably incomplete coverage and volatility. Some products cannot be internationally traded by definition such as government services (e.g. defense, public administration, mostly health and education services). Other services are not usually subject to international trade due to notion of such services - real estate services, personal services. Moreover, an exchange rate may be affected by market speculations, an exchange-rate regime etc. Therefore, the International Comparison Program was established to overcome difficulties in international comparison about fifty years ago (International Bank for Reconstruction and Development and World Bank, 2013). As a result, sophisticated methodology has been developed and can be found in Eurostat-OECD Methodological Manual on Purchasing Power Parities. In a nutshell, an artificial currency Purchase Power Standard (PPS) and so-called Purchase Power Parities (PPPs) have been introduced for international comparison. The same amount of products can be purchased in all 
countries for one PPS that is equal to average euro ${ }^{1}$. A transformation from indicators at national currency to PPS is made using PPPs that express price relation between PPS and national currency.

Estimation of PPPs is described in the above-mentioned Eurostat-OECD Methodological Manual on Purchasing Power Parities in detail. In brief, expenditure approach to GDP is applied in calculation. Each expenditure component is divided into basic headings that represent the minimum level of aggregation. PPPs are estimated for each basic heading using prices of representatives collected in all countries. Each country defines representatives that are typical in a country. Laspeyres price or volume index refers to index with weights from basic period while current weights are used in Paasche index. Similarly, Laspeyres index in context of international comparison refers to spatial index in which prices of products representatives in the base country are included. Paasche spatial index is calculated using price of products representatives in the partner country. Laspeyres, Paasche and Fisher type of PPPs metrices are calculated for each basic heading and each pair of countries using collected prices. If prices are missing PPPs matrices are estimated using other countries as a bridge. In order to ensure transitivity of PPPs EKS (Éltetö-Köves-Szulc) method is applied (more about EKS or Gini-Éltetö-Köves-Szulc (GEKS) in International Bank for Reconstruction and Development and World Bank, 2013). Finally, PPPs are standardised to a joint base. The calculation is carried out for each basic heading, which represents the most detailed level of calculation. PPPs can be aggregated using Fisher type of indices (geometric average of Laspeyres and Paasche indices). Laspeyres indices employ weights in base country whereas Paasche indices are based on weights in partner country. Subsequently, Fisher indices are calculated and EKS method is applied. Finally, PPPs are standardized in order to reach the base.

\subsection{Regional comparison of economic indicators}

National PPPs facilitate international comparison of indicators of national accounts as well as other statistics such as average wage. One may find in official statistics even regional indicators such as regional GDP in PPS. It should be noted that regional national accounts are based on the same methodology, however, data can be less reliable as data source are limited. It is worth mentioning that GDP is an indicator of economic performance that may especially for small areas differ from national income generated from economic activity due to inflows and outflows of income from/to other regions or countries. Moreover, Regional Purchase Power Parities (hereinafter RPPPs) are not actually estimated by international institutions. As a result, regional indicators are transformed to PPS using national PPPs. It has been proved that price levels among regions within one country differ. Experience from Spain can be found in Alberola and Marques (2001), from Germany in Roos (2006), from the United Kingdom in Johnston and Bailey (2011), from Poland and USA in Rokicki and Hewings (2016) and from the USA in Aten et al. (2011).

Officially, RPPPs are not estimated due to lack of data sources. Expenditure components of regional GDP are available almost in no country as well as price statistics does not offer data in regional breakdown. Nevertheless, demand for the regional data is quite strong and researchers' teams worldwide are dealing with the estimation of regional price levels in different countries using various approaches.

The researcher team of the University of Economics started its research about a decade ago. First regional price levels for the Czech Republic were estimated for the year 2007 (Čadil et al., 2014). The developed methodology was inspired by Eurostat/OECD's methodology with adjustments justified by limited data sources and other conditions. Regional price levels

\footnotetext{
${ }^{1}$ Besides PPS other artificial currencies are used, e.g. constant dollar.
} 
cover only household consumption expenditure and not the whole GDP. Notwithstanding the interest is usually aimed at analysing household incomes, expenditures and well-being for which above mentioned fact does not represent an obstacle in application. Apart from International Comparison Program, no specialised survey is used. Such surveys and models are designed for international comparison but collected data or results are not reliable or even available at the regional level. Various data sources were used in the calculation among the most important is consumer price survey and data from national accounts, which serve as the data source for dwelling services. Because of similarity of Czech regions simpler methods for missing data were used as well as no quality adjustment was employed. However, calculation was carried out at the level of representatives (about 700 items) instead of basic headings (only 200 items), for details see Čadil et al. (2014).

The estimates were later updated for the year 2012 (Kramulová et al., 2016). The update required some changes in methodology requested mainly by substantial changes in data collection for consumer price index and new standard of national accounts (ESA 2010).

No substantial methodological change is present between methodology for 2017 and 2012 as no important alternation has occurred since 2012. The main data sources are price statistics (collected regional average prices, detailed weights of representatives) and national accounts (housing services, structure of expenditure in division by COICOP). The results of our previous research focused on regional differences in consumption (Kramulová and Musil, 2013) are also utilised. A share of products purchased on-line has been increasing which is followingly reflected in consumer basket. Consequently, it leads to the elimination of price differences among regions. However, prices disparities are mainly caused by housing services and personal services for which no reduction in differences is observed.

\section{Results}

Figure 1 below presents the results of RPPPs for the year 2017 in Czech NUTS 3 regions in a choropleth map.

Figure 1: RPPPs for the year 2017 (in \%)

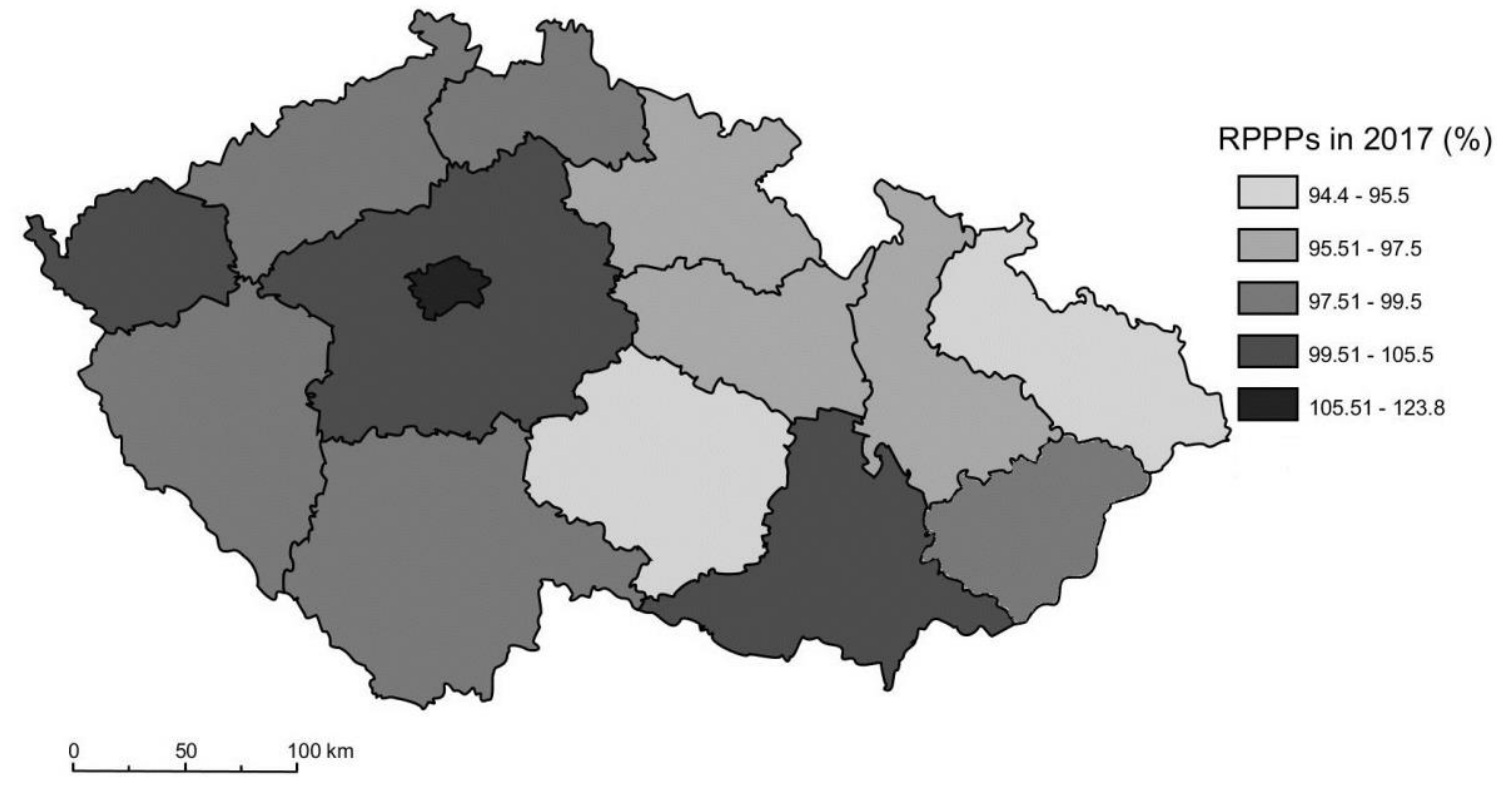

Source: the authors.

We can see that only four regions have the RPPP greater or equal to $100 \%$, i.e. the national average. These are regions containing two biggest cities in the Czech Republic (Capital city Praha containing Prague and Jihomoravský region containing Brno), Středočeský region 
covering suburbs of the city of Prague and Karlovarský, which is specific due to its very small area. Value of RPPP of Capital city Praha is $23.8 \%$ higher than average of Czech Republic. All other regions range between 94.4 and $99.3 \%$.

Table 1 below depicts the main wage indicators as well as the application of regional price levels on these indicators. As to nominal indicators, which are expressed in CZK without any adjustments, the highest figures are observed in Capital city Praha where nominal average wage is $27.9 \%$, while median is $18.8 \%$ above the national average. Above average wages measured by mean are recorded in Středočeský region only (1.1\% above national average). In respect of wage median, the highest one is observed in Středočeský region $(3.2 \%$ above national median) and Plzeňský region (3.9\% above national median). The lowest average wage is in Karlovarský region (86.8\% of national average) but the lowest wage median is seen in Zlínský region (92.4\% of national median). It may be explained by differences in wage distributions among regions.

Well-being of households measured by nominal average wage or nominal wage median seems to be the highest in the capital city. However, if the above mentioned indicators are adjusted to the same price level, conclusions are different. Supreme average wage remains in Capital city Praha (3.3\% above national average) whereas other regions drop below the average. Adjusted wage median is the highest in Plzeňský region (4.6\% above national median), Vysočina region (1.7\% above national median) and Liberecký region $(0.4 \%$ above national median) while Královehradecký region is on average and others below the national average. Median in Capital city Praha is the $4^{\text {th }}$ lowest in the Czech Republic that may been in contradiction with the previous results. The gap between average and median is substantial in the capital city (about 25\%) while in other regions is minor (around 10\%). Well-being of households in the capital city working for median wage is worse than national standard.

Section 4 will discuss the results in comparison with earlier estimations of RPPPs for the years 2007 and 2012.

Table 1: Average and median wage for the year 2017

\begin{tabular}{lcccc}
\hline \multicolumn{1}{c}{ Region } & $\begin{array}{c}\text { Average wage in } \\
\text { CZK }\end{array}$ & $\begin{array}{c}\text { Average wage in } \\
\text { RPPS }\end{array}$ & $\begin{array}{c}\text { Wage median in } \\
\text { CZK }\end{array}$ & $\begin{array}{c}\text { Wage median in } \\
\text { RPPS }\end{array}$ \\
\hline Capital city Praha & 39782 & 32140 & 31878 & 25754 \\
Středočeský region & 31457 & 29916 & 27709 & 26352 \\
Jihočeský region & 28093 & 28797 & 25457 & 26095 \\
Plzeňský region & 30700 & 30923 & 27879 & 28082 \\
Karlovarský region & 26999 & 26997 & 24832 & 24830 \\
Ústecký region & 28369 & 29029 & 25639 & 26235 \\
Liberecký region & 29121 & 29338 & 26752 & 26951 \\
Královéhradecký region & 28580 & 29648 & 25865 & 26832 \\
Pardubický region & 28006 & 29052 & 25507 & 26460 \\
Vysočina region & 28568 & 30257 & 25783 & 27307 \\
Jihomoravský region & 30311 & 29284 & 26559 & 25659 \\
Olomoucký region & 27486 & 28496 & 24956 & 25873 \\
Zlínský region & 27565 & 28110 & 24814 & 25304 \\
Moravskoslezský region & 27991 & 29402 & 25534 & 26821 \\
Czech Republic & 31109 & 31109 & 26843 & 26843 \\
\hline Source: the & & & & \\
\hline
\end{tabular}

Source: the authors.

\section{Discussion}

At the beginning, we are going to compare the results of three estimates from the years 2007, 2012 and 2017. Table 2 shows RPPPs in all three years and the differences. 
Table 2: RPPPs in \% and differences in percentage points for the years 2007, 2012 and 2017

\begin{tabular}{lccccc}
\hline \multicolumn{1}{c}{ Region } & $\begin{array}{c}\text { RPPP 2007 } \\
(\%)\end{array}$ & $\begin{array}{c}\text { RPPP 2012 } \\
(\%)\end{array}$ & $\begin{array}{c}\text { RPPP 2017 } \\
(\%)\end{array}$ & $\begin{array}{c}\text { RPPP difference } \\
\text { 2012-2007 (p.p.) }\end{array}$ & $\begin{array}{c}\text { RPPP difference } \\
\text { 2017-2012 (p.p.) }\end{array}$ \\
\hline Capital city Praha & 120.8 & 122.3 & 123.8 & 1.5 & 1.4 \\
Středočeský region & 102.6 & 106.3 & 105.2 & 3.7 & -1.2 \\
Jihočeský region & 97.5 & 99.0 & 97.6 & 1.5 & -1.4 \\
Plzeňský region & 97.1 & 100.0 & 99.3 & 2.9 & -0.7 \\
Karlovarský region & 101.3 & 99.9 & 100.0 & -1.3 & 0.1 \\
Ústecký region & 94.1 & 96.7 & 97.7 & 2.6 & 1.1 \\
Liberecký region & 100.2 & 100.5 & 99.3 & 0.3 & -1.3 \\
Královéhradecký region & 96.2 & 96.7 & 96.4 & 0.5 & -0.3 \\
Pardubický region & 98.9 & 96.2 & 96.4 & -2.7 & 0.2 \\
Vysočina region & 95.1 & 93.1 & 94.4 & -2.0 & 1.3 \\
Jihomoravský region & 104.6 & 100.6 & 103.5 & -3.9 & 2.9 \\
Olomoucký region & 96.6 & 96.9 & 96.5 & 0.3 & -0.4 \\
Zlínský region & 100.8 & 97.5 & 98.1 & -3.3 & 0.6 \\
Moravskoslezský region & 96.9 & 97.2 & 95.2 & 0.3 & -2.0 \\
Czech Republic & 100.00 & 100.0 & 100.0 & 0.0 & 0.0 \\
\hline Source Čadilet al. & $2014)$ & $2007, \mathrm{~K}$ & & & \\
\hline
\end{tabular}

Source: Čadil et al. (2014) for 2007, Kramulová et al. (2016) for 2012, the authors for 2017.

We can emphasise that the results are not significantly different among the years. The maximum difference (regardless sign) equals 3.9 percentage points between 2012 and 2007 and 2.9 percentage points between 2017 and 2012. Generally, the differences are lower when comparing the years 2017 and 2012.

Price level in Prague has been increasing since 2007 as the difference between 2017 and 2012 is 1.4 p.p, 2.9 p.p. compared to 2007 respectively. Středočeský region presents surroundings of the capital city where the price level is slightly above the average without significant fluctuation in all years. Similarly, Jihomoravský region is above the average with a temporary drop in 2012. The lowest level is observed in rural Vysočina region 2012 and 2017 while Ústecký region recorded the lowest price level 2007 but the second region was Vysočina region.

Regional price levels can be used to revaluation of nominal regional indicators to real regional indicators considering regional price differences. Estimated regional price levels are applicable on incomes or expenditures of households as they are based on household final consumption expenditure. The application on GDP is questionable as other expenditure components are not included. Although household consumption expenditure constitutes about a half of GDP, the structure of expenditure components varies substantially (Sixta and Vltavská, 2016).

These results can be easily applied at many economic indicators such as wages, pensions or e.g. net disposable income (NDI). Kramulová et al. (2016) explain that "Net disposable income of households represents income in national accounts concept.". Figure 2 below shows one of the applications - comparison of NDI per capita in Czech regions using regional price levels in 2017. The differences between the years 2017 and 2012 and 2012 and 2007 are also included. We can see quite huge negative differences in case of Středočeský region, whereas huge positive differences can be seen in Karlovarský region.

The highest nominal NDI is recorded in Prague (about $1 / 3$ above national average) followed by Středočeský region and Plzeňský region which are above the average as well. On the contrary, the lowest NDI is observed in Ústecký region, which is considered structurally affected by transformation from centralised to market economy, in all years. Nominal indicators are transformed to real indicators using RPPPs. It is obvious that differences in real indicators are significantly lower than in case of nominal indicators. Prague remains the richest region however, the real income is only about $8 \%$ above the national average. NDI in Středočeský region dropped from the above average category to the below average category. 
Figure 2: NDI per capita in Czech regions using regional price levels in 2017 (in \%) and differences in NDI per capita (in percentage points)

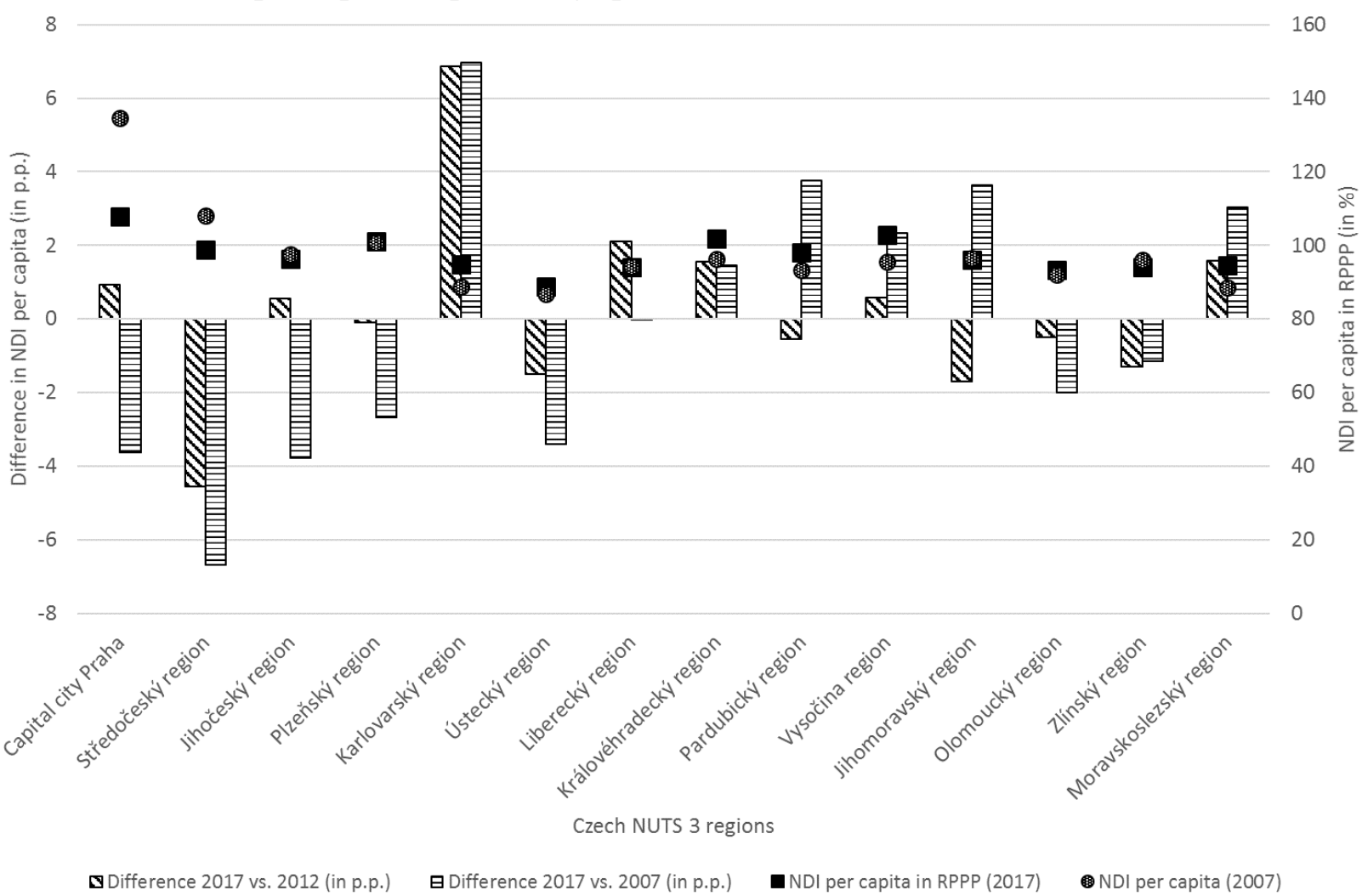

Source: the authors.

\section{Conclusion}

This paper resulted from endless demand on updating of previously estimated regional price levels in 14 Czech NUTS 3 regions. These first estimates covered years 2007 and 2012 and this paper brings new estimates for the year 2017. These are based on the same methodology as earlier, however, some partial adjustments needed to be done (not as big as in case of ESA 2010 revision in 2012 estimates).

The results are very similar to previous two estimates, what shows that there are not big changes in price levels in Czech regions. The highest price level remains in Capital city Praha, moreover, relative prices have been increasing. Sředočeský region, which forms surroundings of the capital city, and Jihomoravský region including the second biggest city are above the average in all years with just a little fluctuation. In the contrary, lower price levels are observed in structurally affected regions.

The paper also shows the application of regional price levels on one of important national accounts indicator - national disposable income. In this case, we can see considerable differences in some regions, contrarily, in some regions the values are almost constant. Without doubt, adjusted indicators are substantially more reliable than unadjusted ones. Regional indicators in PPS are sometime subject to criticism that regional differences in prices are not considered. It should be noted that it is impossible to estimate a full set of regional indicators in regional PPS due to lack of data sources for national accounts as well as from price statistics. This field is subject to academic research in some countries that results in estimated regional price levels. Of course, the results are considered less reliable than the national indicators because of missing and limited data sources. 
The updated regional price levels may be applied in the follow-up research aimed at various areas - economic indicators, wage analysis, poverty analysis, convergence of regions etc. We analysed the impact of different regional price levels on the key income indicators. Unsurprisingly, regional differences in incomes became less significant. Moreover, wage median in the capital city fell below the national average. Follow-up analysis will be subject to our future research.

\section{References}

[1] Alberola, E., Marques, J. M. 2001. On the evolution of relative prices and its nature at the regional level: The case of Spain. In Journal of Regional Science, 2001, vol. 41, iss. 3, pp. 451-474.

[2] Aten, B. H., Figueroa, E. B., Martin, T. M. 2011. Research spotlight: Regional price parities by expenditure class, 2005 - 2009. In Survey of Current Business, 2011, vol. 91, iss. 5, pp. 73-87.

[3] Bajgar, M., Janský, P. 2015. Skutečná kupní síla v krajích České republiky: zohlednění regionální cenové hladiny a struktury pracovní síly. In Politická Ekonomie, 2015, vol. 63, iss. 7, pp. 860-876.

[4] Čadil, J. et al. 2014. True regional purchasing power: Evidence from the Czech Republic. In Post-Communist Economies, 2014, vol. 26, iss. 2, pp. 241-256.

[5] European Commission and OECD 2012. Eurostat-OECD methodological manual on purchasing power parities. 2nd ed. Luxembourg : Publications Office of the European Union, 2012. ISBN 978-92-79-25983-8.

[6] International Bank for Reconstruction and Development, World Bank. 2013. Measuring the real size of the world economy. The framework, methodology, and results of the International Comparison Program - ICP. Washington, D.C.: World Bank, 2013. ISBN 978-0-8213-9731-2.

[7] Janský, P., Kolcunová, D. 2017. Regional differences in price levels across the European Union and their implications for its regional policy. In Annals of Regional Science, 2017, vol. 58 , iss. 3 , pp. 641-660.

[8] Johnston, S., Bailey, S. 2011. UK relative regional consumer price levels for goods and services for 2010. [cit. 2015-03-31] http://www.ons.gov.uk/ons/rel/cpi/regionalconsumer-price-levels /2010/ uk-relative-regional-consumer-price-levels-for-goods-andservices-for-2010.pdf

[9] Kocourek, A., Šimanová, J., Šmída, J. 2016. Estimation of regional price levels in the districts of the Czech Republic. In Statistika: Statistics \& Economy Journal, 2016, vol. 96, iss. 4, pp. 56-70.

[10]Kramulová, J., Musil, P. 2013. Experimentální odhad složek výdajové metody regionálního HDP v ČR. In Politická ekonomie, 2013, vol. 61, iss. 6, pp. 814-833.

[11] Kramulová, J. et al. 2016. Regional price levels in the Czech Republic - past and current perspectives. In Statistika: Statistics \& Economy Journal, 2016, vol. 96, iss. 3, pp. 22-34.

[12] Rokicki, B., Hewings, G. J. D. 2016. Regional convergence within particular country - an approach based on the regional price deflators. In Economic Modelling, 2016, vol. 57, pp. 171-179.

[13] Rokicki, B., Hewings, G. J. D. 2019. Regional price deflators in Poland: Evidence from NUTS-2 and NUTS-3 regions. In Spatial Economic Analysis, 2019, vol. 14, iss. 1, pp. 88-105. 
[14]Roos, M. W. M. 2006. Regional price levels in Germany. In Applied Economics, 2006, vol. 38, iss. 13, pp. 1553-1566.

[15] Sixta J., Vltavská K. 2016. Regionální input-output tabulky: praktické aspekty jejich sestavování pro kraje Česke republiky. In Ekonomický časopis, 2016, vol. 64, iss. 1, pp. $56-69$. 